\title{
ANALISIS TINGKAT LITERASI DIGITAL DAN PENERAPAN E-COMMERCE PADA USAHA MIKRO KECIL DAN MENENGAH DI KOTA SEMARANG
}

\author{
DIGITAL LITERATION LEVEL ANALYSIS AND E-COMMERCE \\ APPLICATION IN SMALL AND MEDIUM MICRO ENTERPRISES IN \\ THE CITY OF SEMARANG
}

\author{
Yohanes Wisnu Djati Sasmito' ${ }^{1}$, Bayu Prestianto \\ wisnu@unika.ac.id
}

\section{Universitas Katolik Soegijapranata}

\begin{abstract}
This study aims to determine the level of digital literacy and the application of e-commerce for Micro, Small and Medium Enterprises (MSMEs) in Semarang City. The approach to assessing literacy levels is based on nine elements of digital literacy developed by Steve Wheeler (2012), namely social networking, transliteracy, maintaining privacy, managing identity, creating content, organizing and sharing content., reusing / repurposing content, filtering and selecting content, and self broadcasting. The data was collected using a survey method by conducting interviews and distributing questionnaires to MSME actors in the city of Semarang. The results of data collection obtained 29 valid respondents. The results of the analysis show that the average aggregate score of the digital literacy level of Micro and Small entrepreneurs (MSEs) is $79.81 \%$. These results cannot provide a judgment about the high or low score, but seeing the phenomenon of understanding this technology, the average score is enough for micro businesses to start adopting and adapting online businesses. The most prominent ability of respondents regarding the 9 components of digital literacy is in understanding and using social media. This is more due to the simplicity of operating social media applications. Meanwhile, those related to content development and managing digital identity are still relatively lacking. This is because content development is not only related to operational mastery of technology but also personal imagination and creativity are very important parts. Of the 29 micro businesses that were selected as respondents, all of them have used social media as part of their business management, while the use of the world wide web still needs improvement, as evidenced by only 4 out of 29 respondents who already have a world wide web (website).
\end{abstract}

Keyword: digital literacy, e-commerce, UMK, UMKM

\begin{abstract}
Abstrak: Penelitian ini bertujuan untuk mengetahui tingkat literasi digital dan penerapan e-commerce pelaku Usaha Mikro Kecil dan Menengah (UMKM) di Kota Semarang. Pendekatan untuk menilai tingkat literasi didasarkan sembilan elemen literasi digital yang dikemukkan oleh Steve Wheeler (2012) dalam tulisannya yang berjudul Digital Literacies For Engagement In Emerging Online Cultures, yaitu social networking, transliteracy, maintaining privacy, managing identity, creating
\end{abstract}


content, organising and sharing content, reusing/repurposing content, filtering and selecting content, serta self broadcasting. Pengumpulan data dilakukan dengan metode survey dengan melakukan wawancara dan penyebaran kuesioner kepada pelaku UMKM di kota Semarang. Hasil pengumpulan data diperoleh 29 reponden yang valid. Hasil analysis menunjukkan rata-rata skor secara agregat tingkat literasi digital dari pengusaha Mikro dan Kecil (UMK) sebesar 79,81\%. Hasil ini belum bisa memberikan judgement tentang tinggi atau rendahnya score tersebut, tetapi melihat fenomena tentang pemahaman terhadap teknologi ini, maka rata-rata skor ini telah cukup bagi usaha mikro untuk memulai mengadopsi dan mengadaptasi bisnis secara online. Kemampuan yang paling menonjol dari responden berkaitan dengan 9 komponen- literasi digital adalah pada pemahaman dan penggunaan media sosial. Hal ini lebih disebabkan oleh kesederhanaan dalam mengoperasikan aplikasi-aplikasi media social. Sedangkan yang berkaitan dengan pengembangan konten dan managing digital identity masih relatif kurang. Hal ini dikarenakan pengembangan konten tidak hanya terkait dengan penguasaan opersional teknologi semata tetapi juga daya imaginasi dan kreativitas personalnya menjadi bagian yang sangat penting. Dari 29 usaha mikro yang terjaring sebagai responden, seluruhnya telah menggunakan media sosial sebagai bagian dari pengelolaan bisnisnya, sedangkan pemanfaatan world wide web masih dirasa perlu ditingkatkan, terbukti hanya 4 dari 29 responden yang telah memiliki world wide web (website).

Kata Kunci: literasi digital, e-commerce, UMK, UMKM

\section{PENDAHULUAN}

Mengapa ekonomi digital menjadi penting dan mendesak untuk dikembangkan? Pertama, realitas saat ini bahwa jumlah pengguna aktif internet di Indonesia mencapai 140 juta pengguna. Ini merupakan peluang yang sangat menjanjikan bagi pembangunan ekosistem digital yang memendam potensi ekonomi yang sangat besar. Kedua, pemanfaatan teknologi informasi memberikan peluang bagi terciptanya system yang efektif di segala bidang, tidak terkecuali di bidang ekonomi dan bisnis. Dengan terciptanya system ekonomi dan bisnis yang efektif akan mendongkrak daya saing. Ketiga, meskipun komunitas digital di Indonesia sangat besar, tetapi kontribusi internet bagi ekonomi Indonesia baru mencapai 4\% dari PDB.

Pertumbuhan pengguna internet yang sangat tinggi berdampak positif bagi perkembangan e commerce di Indonesia. Tercatat pada tahun 2014, Indonesia telah menjadi pasar e-commerce terbesar di Asia Tenggara dengan jumlah transaksi ecommerce mencapai nilai Rp. 25,1 Triliun. Jumlah ini terus meningkat dari tahun ke tahun hingga tercatat transaksi e-commerce di Indonesia sepanjang tahun 2018 
JEMAP: Jurnal Ekonomi, Manajemen, Akuntansi, dan Perpajakan

ISSN: 2622-612X (Media Online) | Vol.4 | No.1 | April 2021

mencapai Rp. 77,766 Triliun. Perkembangan pemanfaatan media digital ini memberikan peluang besar bagi tumbuhnya ekonomi indonesia, yang saat ini didominasi oleh Usaha Mikro Kecil dan Menengah (UMKM). Dominasi UMKM dalam struktur perekonomian Indonesia menjadi alasan utama mengapa pemerintah sangat serius menjadikan UMKM sebagai salah satu platform agenda pembangunan ekonomi dan sosial di Indonesia. Kebijakan ini dianggap tepat karena, pertama, secara kuantitatif jumlah UMKM mencapai 99,9\% dari total unit usaha di Indonesia. Kedua, UMKM mempunyai kemampuan menyerap tenaga kerja sangat signifikan, yaitu sekitar sebesar 97,22\% dari total angkatan kerja di Indonesia. Ketiga, kontribusi UMKM terhadap produk domestik bruto (PDB) mencapai 60,34\%, sedangkan dari sisi ekspor, UMKM menyumbang 15,8\% dari total ekspor Indonesia.

Kondisi ini tentu juga menarik perhatian pemerintah daerah, termasuk jawa tengah khususnya kota Semarang, untuk memanfaatkan infrastruktur teknologi informasi ini dalam mengembangkan perekonomian yang menyentuh pada seluruh lapisan masyarakat. UMKM di kota Semarang pada akhir pertengahan tahun 2019 telah mencapai 17.091 unit UMKM dengan tingkat pertumbuhan rata-rata 1,97\% per tahun. Jumlah ini menyebar di 16 Kecamatan dengan jumlah tertinggi di wilayah Kecamatan Pedurungan. Dalam struktur industri kota Semarang, jumlah UMKM di Kota Semarang mempunyai porsi lebih dari 99\% dari keseluruhan usaha. Untuk itu peningkatan peran UMKM tidak hanya sebagai penggerak perekonomian tetapi juga sebagai alat pemerataan dan stabilitas perekonimian harus ditingkatkan. Peningkatan kualitas pengelolaan manajerial dan penguatan pemanfaat teknologi perlu dipertimbangkan untuk meningkatkan daya saing UMKM kota Semarang. Dalam acara Bimtek tentang pemanfaatan teknologi untuk UMKM Pariwisata, pada tanggal 29 Agustus 2019, Sekretaris Daerah Kota Semarang Iswar Aminudin mengatakan, Pemerintah Kota Semarang siap memberikan sarana dan prasarana agar UMKM di Kota Semarang dapat menembus pasar ekonomi ASEAN. Oleh karena itu pemanfaatan teknologi digital sebagai sarana untuk menembus pasar ASEAN atau bahkan pasar global harus ditingkatkan. Dalam acara tersebut dikatakan bahwa pemanfaatan teknologi digital di UMKM masih tergolong rendah. Hal ini juga diperkuat oleh penelitian yang dilakukan oleh Lubis dan Junaidi (2016) menyatakan 
masih rendahnya pemanfaatan teknologi informasi pada UMKM yang disebabkan oeh rendahnya pemahaman terhadap manfaat teknologi informasi; rendahnya ketersediaan investasi; dan rendahnya dukungan lembaga pemerintah. Belum optimalnya pemanfaatan teknologi digital ini juga tercermin dalam fakta data tentang kontribusi e- commerce bagi PDB Indonesia. Meskipun secara nominal kontribusi e-commerce tahun 2017 sebesar Rp 125 triliun. Nilai ini hanya mengkontribusi sebesar 0,9\% terhadap PDB yang sebesar Rp 13.588,8 triliun. Jika mengacu pada proyeksi PWC bahwa PDB Indonesia bakal menyentuh US\$12.475 pada 2030, maka kontribusi $e$ commerce meningkat hanya menjadi $1,4 \%$ terhadap PDB.

Fenomena ini menjadi menarik untuk dikaji secara mendasar mengapa ini terjadi. Jika melihat struktur usaha di Indonesia didominasi oleh UMKM maka tidak ada cara yang lebih jitu selain memberdayakan UMKM ini untuk masuk ke dalam teknologi digital. Pertanyaannya adalah bagaimana kesiapan UMKM dalam mengadopsi teknologi Digital, mengingat perkembangan teknologi digital yang begitu pesat tanpa diikuti dengan upaya peningkatan pengetahuan dan pemahaman secara masif, hanya akan menambah deviasi antara keduannya. Untuk itu perlu ada kajian yang mendalam mengenai seberapa jauh tingkat literasi dan pemanfaatan teknologi UMKM di Indonesia sehingga strategi internalisasi teknologi dikalangan UMKM dapat dilakukan sesuai dengan kebutuhannya. Untuk itu, dalam penelitian ini akan dilakukan analisis terhadap tingkat literasi dan penerapan e-commerce pada UMKM, dimana Kota Semarang menjadi wilayah obyek penelitian.

\section{Tujuan Penelitian}

Tujuan penelitian ini adalah :

1. Mengetahui tingkat literasi Digital pelaku Usaha Mikro Kecil dan Menengah di Kota Semarang.

2. Mengetahui penerapan $e$-Commerce pelaku Usaha Mikro Kecil dan Menengah di Kota Semarang. 
JEMAP: Jurnal Ekonomi, Manajemen, Akuntansi, dan Perpajakan

ISSN: 2622-612X (Media Online) | Vol.4 | No.1 | April 2021

\section{LANDASAN TEORI}

\section{Literasi Digital}

Menurut Paul Gilster dalam bukunya yang berjudul Digital Literacy (1997), literasi digital diartikan sebagai kemampuan untuk memahami dan menggunakan informasi dalam berbagai bentuk dari berbagai sumber yang sangat luas yang diakses melalui piranti komputer. Bawden (2001) menawarkan pemahaman baru mengenai literasi digital yang berakar pada literasi komputer dan literasi informasi.

Elemen penting literasi digital adalah menyangkut kemampuan apa saja yang harus dikuasai dalam pemanfaatan tekonologi informasi dan komunikasi. Steve Wheeler (2012) dalam tulisannya yang berjudul Digital Literacies For Engagement In Emerging Online Cultures, mengidentifikasi ada sembilan elemen penting dalam dunia litersi digital yaitu social networking, transliteracy, maintaining privacy, managing identity, creating content, organising and sharing content, reusing/repurposing content, filtering and selecting content, serta self broadcasting. Social Networking berkaitan semakin berkembangnya berbagai aplikasi jejaring social yang menawarkan beragam fitur yang berbeda. Memanfaatkan layanan situs jejaring sosial perlu selektif dan kehati-hatian. Pengetahuan dan pemetaan penggunaan situs jejaring sosial berdasarkan fungsinya dan kemampuan menggunakan jejaring social dengan berbagai fitur yang ditawarkan sangat diperlukan. Untuk itu, perlu mengetahui sekaligus menguasai fungsi-fungsi dasar dari setiap fitur yang ada. Disisi lain etika pemanfaatan situs jejaring sosial juga tidak luput dari perhatian. Literasi digital memberikan jalan bagaimana seharusnya berjejaring sosial yang baik itu. Transliteracy diartikan sebagai kemampuan memanfaatkan segala platform yang berbeda khususnya untuk membuat konten, mengumpulkan, membagikan hingga mengkomunikasikan melalui berbagai media sosial, grup diskusi, smartphone dan berbagai layanan online yang tersedia. Maintaining Privacy atau menjaga privasi dalam dunia online perlu memahami dari segala jenis cybercrime seperti pencurian online lewat kartu kredit (carding), mengenal ciri-ciri situs palsu (phishing), penipuan via email dan lain sebagainya. Menampilkan identitas online hanya seperlunya saja untuk menghindari sesuatu hal yang tidak 
JEMAP: Jurnal Ekonomi, Manajemen, Akuntansi, dan Perpajakan

ISSN: 2622-612X (Media Online) | Vol.4 | No.1 | April 2021

diinginkan. Managing Digital Identity berkaitan dengan bagaimana cara menggunakan identitas yang tepat diberbagai jaringan sosial dan platform lainya. Creating Content berkaitan dengan suatu ketrampilan tentang bagaimana caranya membuat konten di berbagai aplikasi online dan platform misalnya di PowToon, Prezi, blog, forum, dan wikis. Selain itu mencakup kemampuan menggunakan berbagai platform e-learning. Organising and Sharing Content adalah mengatur dan berbagi konten informasi agar lebih mudah tersebarkan. Misalnya pada pemanfaatan situs social bookmarking memudahkan penyebaran informasi yang bisa diakses oleh banyak pengguna di internet. Reusing/repurposing Content kemampuan membuat konten dari berbagai jenis informasi yang tersedia hingga menghasilkan konten baru dan dapat dipergunakan kembali untuk berbagai kebutuhan. Misalnya seorang guru yang membuat konten tentang mata pelajaran tertentu dengan lisensi creative common. Kemudian konten tersebut diunggah di website Slideshare sehingga akan banyak yang mengunduhnya. Lalu konten tersebut bisa digunakan oleh orang lain yang membutuhkan dengan menambahkan informasi atau pengetahuan baru agar lebih lengkap sesuai kebutuhannya. Filtering and Selecting Content adalah Kemampuan mencari, menyaring dan memilih informasi dengan tepat sesuai dengan kebutuhan yang diinginkan misalnya lewat berbagai mesin pencari di internet. Self Broadcasting bertujuan untuk membagikan ide-ide menarik atau gagasan pribadi dan konten multimedia misalnya melalui blog, forum atau wikis. Hal tersebut adalah bentuk partisipasi dalam masyarakat sosial online.

\subsection{Usaha Mikro Kecil dan Menengah (UMKM)}

Kementerian Koperasi dan UKM RI melaporkan bahwa secara jumlah unit, UMKM memiliki pangsa sekitar 99,99\% (62.9 juta unit) dari total keseluruhan pelaku usaha di Indonesia (2017), sementara usaha besar hanya sebanyak 0,01\% atau sekitar 5.400 unit. Usaha Mikro menyerap sekitar 107,2 juta tenaga kerja (89,2\%), Usaha Kecil 5,7 juta (4,74\%), dan Usaha Menengah 3,73 juta (3,11\%); sementara Usaha Besar menyerap sekitar 3,58 juta jiwa. Artinya secara gabungan UMKM menyerap sekitar 97\% tenaga kerja nasional, sementara Usaha Besar hanya menyerap sekitar $3 \%$ dari total tenaga kerja nasional. 
Di Indonesia Undang-Undang yang mengatur tentang UMKM adalah UU No. 20/2008, dalam UU tersebut UMKM dijelaskan sebagai: "Perusahaan kecil yang dimiliki dan dikelola oleh seseorang atau dimiliki oleh sekelompok kecil orang dengan jumlah kekayaan dan pendapatan tertentu."

Sebuah Usaha dapat dikategorikan ke dalam Usaha Mikro apabila memiliki aset maksimal Rp 50 juta dan omzet maksimal Rp 300 juta per tahun atau sekitar Rp1.000.000 per hari (asumsi beroperasional aktif selama 300 hari/tahun); sementara batas atas omzet untuk Usaha Kecil adalah sekitar Rp 8,3 juta per hari; dan batas atas omzet Usaha Menengah adalah sekitar Rp 167juta per hari. Kini kita dapat menentukan sendiri apakah usaha yang kita jalankan termasuk dalam usaha skala mikro, kecil, atau menengah dengan merujuk pada kriteria UMKM di atas.

Disamping klasifikasi usaha berdasarkan asset dan omset yang termaktub dalam UU No.20/2008, beberapa lembaga menggunakan kriteria jumlah tenaga kerja guna mengklasifikasikan usaha mikro, kecil dan menegah. World Bank mengklasifikasikan UMKM menjadi tiga jenis dengan menggunakan pendekatan berdasarkan jumlah karyawan, pendapatan dan aset yang dimilikinya. Usaha Mikro Jumlah karyawan $<10$ orang Pendapatan setahun $<\$ 100$ ribu Kepemilikan aset $<$ $\$ 100$ ribu. Usaha Kecil Jumlah karyawan < 30 orang Pendapatan setahun < US \$3 juta Kepemilikan aset < US \$3 juta Usaha Menengah Jumlah karyawan maksimal 300 orang Pendapatan setahun US\$15 juta Kepemilkan aset mencapai US \$15 juta. Demikian juga Badan Pusat Statistik Badan Pusat Statistik (BPS) mengklasifikasikan berdasarkan kuantitas tenaga kerja yang digunakan pada setiap unit usaha yaitu: Usaha Kecil: tenaga kerja 5-19 orang. Usaha Menengah: tenaga kerja 20-99 orang.

\section{METODOLOGI}

\section{Populasi dan Sampel}

Populasi dalam penelitian ini adalah seluruh UMKM dengan kriteria menurut undang-undang Republik Indonesia No. 20 tahun 2008 di Kota Semarang. Menurut data statistic dari BPS (www.bps.go.id) jumlah UMKM sampai dengan pertengahan tahun 2019 mencapai 17.091 unit. Metode pengambilan sampel dalam penelitian ini menggunakan metode random purposive sampling dengan kriteria UMKM yang aktif menggunakan media e-commerce untuk melakukan aktivitas pemasaran dan 
penginformasian produknya. Penyebaran kuesioner dilakukan secara acak kepada UMKM yang memenuhi kriteria sebanyak 200 responden. Teknik pengambilan data menggunakan teknik wawancara dan kuesioner yang dibagikan kepada seluruh sampel penelitian.

\section{Analisis Data}

Dalam Kajian Penelitian ini dibutuhkan analisis secara kuantitatif dan kualitatif untuk mengeksplorasi tingkat literasi dan penerapan e-Commerce bagi operasi dan pengembangan bisnis UMKM. Secara kuantitatif data yang terkumpul akan di sajikan dalam bentuk cross table dengan melakukan pencacahan berdasarkan pada kelompok tertentu, misalnya jenis media social yang digunakan, jenis produk, jenis responden, umur, gender dan wilayah.

Dalam kajian Kualitatif terdapat beberapa teknik analisis data, di antaranya adalah teknik siklus sebagaimana disampaikan oleh Milles dan Hubberman. Dalam teknik analisis ini semua data yang terkumpul dapat diseleksi secara ketat (melalui reduksi) sehingga data yang akan dianalisis nantinya merupakan data yang valid dan relevan sebagaimana dipersyaratkan dalam kajian kualitatif.

Analisis data pada kajian kualitatif meliputi tahap-tahap sebagai berikut (Milles and Huberman, 1992):

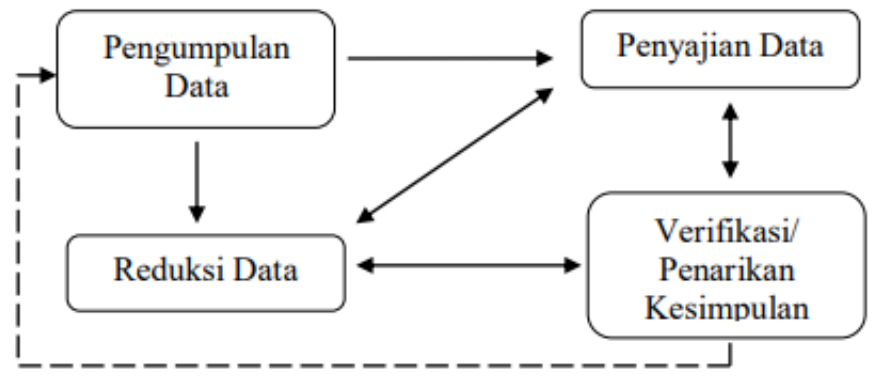

\section{Analisis Kuantitatif Milles and Huberman}

Reduksi data (data reduction), yaitu data yang diperoleh di lokasi kajian (data lapangan) dituangkan dalam uraian atau laporan yang lengkap dan terinci. Laporan lapangan akan direduksi, dirangkum, dipilih hal-hal pokok, difokuskan pada hal-hal yang penting kemudian dicari tema atau polanya. Selama pengumpulan data 
JEMAP: Jurnal Ekonomi, Manajemen, Akuntansi, dan Perpajakan

ISSN: 2622-612X (Media Online) | Vol.4 | No.1 | April 2021

berlangsung diadakan tahap reduksi data, selanjutnya membuat ringkasan, mengkode, menelusuri tema, membuat gugus-gugus dan menulis memo.Penyajian data (data display), yaitu memudahkan bagi peneliti untuk melihat gambaran secara keseluruhan atau bagian tertentu dari kajian. Penarikan kesimpulan (conclucing drawing), yaitu melakukan verifikasi secara terus menerus sepanjang proses kajian berlangsung, yaitu sejak awal memasuki lokasi kajian dan selama proses pengumpulan data. Peneliti berusaha untuk menganalisis dan mencari pola, tema, hubungan persamaan, hal-hal yang sering muncul, hipotesis dan sebagainya yang dituangkan dalam kesimpulan yang tentatif.

\section{HASIL DAN PEMBAHASAN}

Populasi penelitian ini adalah Usaha Mikro Kecil dan Menengah (UMKM) di wilayah kota Semarang. Populasi tersebar di 16 wilayah kecamatan yang berjumlah 17.091 unit UMKM dengan tingkat pertumbuhan rata-rata 1,97\% per tahun (BPS, 2019). Penyebaran kuesioner dilakukan melalui Google Form dengan link https://docs.google.com/forms/d/1dLpRG6ax9pHc5rMN790UL5Ew82QE5QJ8kUw $\underline{\mathrm{IUJ}-b B r s / \text { viewform? }}$ edit_requested=true. Mekanisme pengumpulan data melalui Google Form dilakukan karena adanya Kondisi Luar Biasa (KLB) Pandemi Covid 19, yang membatasi interaksi antara peneliti dan subyeknya. Berdasarkan teknik accidental sampling terkumpul 34 (tiga puluh empat) responde pengusaha Usaha Mikro Kecil dan Menengah yang bersedia menjadi sampel. Setelah diidentifikasi, dari 34 responden tersebut terdapat 3 responden berasal dari luar wilayah kota Semarang dan 2 responden melakukan dua kali pengisian kuesioner. Sehingga terdapat 5 responden yang dihilangkan dari sampel, sehingga jumlah responden yang valid menjadi 29.

\section{Literasi Digital}

Beberapa waktu yang lalu kementerian Koperasi dan Usaha Kecil dan Menengah meluncurkan program Kakak Asuh UMKM (KAU) untuk mempercepat upaya transformasi digital para pelaku UMKM, terutama melalui online marketplace. Melalui KAU, KemenKopUKM akan mencetak para ahli digital marketing yang akan 
JEMAP: Jurnal Ekonomi, Manajemen, Akuntansi, dan Perpajakan

ISSN: 2622-612X (Media Online) | Vol.4 | No.1 | April 2021

bertindak sebagai kakak asuh, yang akan mendampingi para pelaku UMKM dalam memanfaatkan marketplace secara lebih efisien. Penelitian ini mempunyai relevansi dengan program KemenKopUKM di atas. Kendala utama UMK dalam mengadaptasi Teknologi Informasi (TI) sebagai bagian dari media bisnis sangat dipengaruhi oleh tingkat literasi digital UMKM terhadap teknologi itu sendiri. Hasil survey yang dilakukan dalam penelitian ini terhadap 29 responden UMK menujukkan hasil sebagai berikut:

\section{Crosstab Komponen Literasi Digital dengan Rata-Rata Jawaban Responden}

\begin{tabular}{|l|r|r|r|}
\cline { 2 - 4 } & \multicolumn{3}{c|}{ Jawaban Responden } \\
\hline Komponen Literasi digital & \multicolumn{1}{c|}{ Ya } & \multicolumn{1}{c|}{ Tidak } & Kosong \\
\hline Social Networking & $96.55 \%$ & $3.45 \%$ & $0.00 \%$ \\
\hline Transliteracy & $97.70 \%$ & $2.30 \%$ & $0.00 \%$ \\
\hline Maintaining Privacy & $96.55 \%$ & $2.07 \%$ & $1.38 \%$ \\
\hline Managing Digital Identity & $51.03 \%$ & $48.97 \%$ & $0.00 \%$ \\
\hline Creating Content & $67.59 \%$ & $32.41 \%$ & $0.00 \%$ \\
\hline Organizing and Sharing Content & $68.97 \%$ & $31.03 \%$ & $0.00 \%$ \\
\hline Reusing/repurposing Content & $61.21 \%$ & $38.79 \%$ & $0.00 \%$ \\
\hline Filtering and Selecting Content & $90.80 \%$ & $9.20 \%$ & $0.00 \%$ \\
\hline Self Broadcasting & $87.93 \%$ & $10.34 \%$ & $1.72 \%$ \\
\hline
\end{tabular}

Sumber: Data Primer diolah 2020

Tabel di atas merupakan skor rata-rata yang diperoleh responden terhadap 9 komponen literasi digital yang dikemukakan oleh Steve Wheeler pada tahun 1997. Tercatat pada tingkat social networking, transliteracy, maintaining privacy dan filtering and selecting content mempunyai tingkat rata-rata score yang sangat tinggi. Terbukti nilai rata-rata score yang dicapai lebih dari $90 \%$. Sedangkan rata-rata score self broadcasting mempunyai nilai yang tinggi sebesar 87,93\%. Score tertinggi diperoleh pada komponen transliteracy sebesar 97,70\%, artinya kemampuan responden dalam mengkombinasikan berbagai media dan aplikasi sangat memadai. Mereka mampu menggunakan media web dan media sosial serta marketplace secara terintegrasi. Score tertinggi ke-2 diperoleh pada komponen social networking sebesar 96,55\%. Hal ini konsisten dengan penerapan e-commerce pada responden, dimana tidak satu pun responden yang tidak menggunakan social media dalam pengelolaan bisnisnya. Meskipun preferensi responden terhadap berbagai social media beragam 
JEMAP: Jurnal Ekonomi, Manajemen, Akuntansi, dan Perpajakan

ISSN: 2622-612X (Media Online) | Vol.4 | No.1 | April 2021

tetapi mereka lebih cenderung menggunakan dua aplikasi social media yaitu whatsapp dan facebook. Konsistensi hasil ini menunjukkan bahwa responden (UMK) lebih cenderung menggunakan social media karena memang tingkat literasi digital terhadap aplikasi social media mempunyai score tinggi pula. Berbeda dengan tingkat literacy yang berkaitan dengan content. Pada tabel di atas 3 komponen yang berkaitan dengan konten memberikan hasil score yang kurang memuaskan. Ketiga score yang berkaitan dengan konten yang memberikan skor kurang memuaskan ada pada komponen creating content, organizing and sharing content dan reusing/repurposing content. Ketiga komponen ini membutuhkan daya kreatitivitas dan imaginasi responden. Kelemahan utama dari usaha mikro dan kecil adalah pada pembentukan product image. Seringkali UMK dalam mengelola usahanya hanya terjebak pada orientasi jangka pendek karena permasalahan utamanya berakar pada keterbatasan aset dan modal. Kecilnya modal yang dimiliki menyebabkan konsentrasi pemasaran mereka hanya berorientasi pada perputaran penjualan yang cepat sehingga sering mengabaikan aspek produk atau brand image. Membangun brand image memang bukan pekerjaan yang mudah dan butuh biaya dan keahlian yang tinggi. Internet dengan potensi pasar yang tinggi menjadi salah satu media yang sebenarnya sangat strategis guna membangun brand image ini. Tetapi syaratnya pebisnis harus punya kreativitas yang tinggi untuk menciptakan konten-konten yang menarik bagi pelanggan dan calon pelanggannya. Pertanyaannya, apakah UMK mempunyai modal dasar yang cukup untuk membuat merk mereka menjadi besar. Hasil penelitian ini menyatakan "belum cukup". Seharusnya ada lembaga yang non profit oriented (pemerintah) yang menjadi jembatan bagi publisitas produk UMK, sehingga tercipta product image UMK yang unggul. Publisitas ini harus dilakukan secara konsisten dengan membuat konten-konten menarik tentang produk-produk UMK dan dikomunikasikan melalui website dan media sosial secara massif. Massif artinya dilakukan secara konsisten dan berkesinambungan dengan frekuensi yang tinggi.

Nilai rata-rata terendah dari keseluruhan komponen literasi digital terdapat pada managing digital identity dengan rata-rata skor sebesar 48,00\%. Rendahnya nilai komponen managing digital identity bisa dikarenakan perbedaan persepsi tentang item-item penyataan yang tertuang dalam kuesioner. Managing digital identity 
berkaitan dengan bagaimana cara menggunakan identitas yang tepat diberbagai jaringan sosial dan platform lainya. Penggunaan identitas dengan nama tersamar seringkali digunakan dalam menjajaki sebuah akun atau situs yang meragukan. Banyak pengguna Internet yang mempunyai lebih dari satu akun dan digunakan untuk keperluan-keperluan yang berbeda-beda. Sebagian responden dalam penelitian ini juga mempunyai double dan bahkan multi akun. Tetapi yang menarik dari pernyataan terakhir yang berkaitan dengan preferensi responden untuk lebih suka menggunakan akun yang tersamar ternyata ditolak oleh $96 \%$ responden. Ha ini mengindikasikan bahwa sebagian besar responden (UMK) menggunakan identitas mereka sebagai brand atau merk. Sehingga identitas yang digunakan selalu identitas riil dan cenderung mengabaikan kemungkinan penyalagunaan terhadap identitas itu untuk kepentingan-kepentingan pihak lain yang tidak bertanggungjawab. Pada item pernyataan ini perlu dilakukan kajian yang lebih dalam tentang persepsi virtual identity bagi pelaku bisnis UMK. Karena identitas yang disamarkan belum tentu sama dengan identitas palsu. Perlu diingat banyak tokoh yang terkenal dan dikenal karena nama samarannya.

Jika dihitung nilai rata-rata secara agregat, skor dari literasi digital responden dalam penelitian ini mencapai 79,81\%. Apakah score ini tergolong tinggi? Tidak ada ukuran yang pasti tentang itu. Tetapi jika dilihat dari kapasitas bisnis dari responden yang sebagian besar adalah usaha mikro dan kecil maka dapat dikatakan score ini cukup untuk sebuah ukuran literasi guna memulai mengadopsi dan mengadaptasi bisnis secara online. Hanya perlu perbaikan beberapa item komponen literasi, utama nya yang berkaitan dengan kemampuan UMK membuat konten-konten yang menarik untuk di broadcast pada pelanggan atau calaon pelanggan. Mungkinkah program Kakak Asuh UMKM (KAU) yang digulirkan kementerian Koperasi dan Usaha Kecil dan Menengah mampu mempercepat upaya transformasi digital para pelaku UMKM.

\section{Implementasi E-Commerce}

E-Commerce merupakan bagian yang tak terpisahkan dari sebuah konsep bisnis modern. Berkembangnya praktek-praktek bisnis online yang memanfaatkan media Internet marak terjadi diberbagai bisnis baik bisnis berskala mikro maupun 
bisnis dengan skala yang sangat besar. Pemanfaatan e-commerce bagi pebisnis mikro dan kecil cenderung terbatas pada sarana untuk mencari pasar bagi produknya. Sedangkan pebisnis besar mempunyai strategi yang sangat beragam dari mulai pembentukan brand image, brand engagement sampai pada implementasi terintegrasi pada system penjualan dan pemeliharaan konsumennya.

Salah satu tujuannya dalam penelitian ini adalah mengetahui penerapan $e$ Commerce pelaku Usaha Mikro Kecil dan Menengah di Kota Semarang. Namun dari 29 responden yang telah bersedia menjadi sampel terdiri dari 26 responden atau $88 \%$ responden adalah usaha mikro sedang 3 responden atau $12 \%$ responden adalah usaha kecil. Berdasarkan pada kondisi diatas maka pembahasan penelitian ini akan fokus pada usaha mikro dan kecil. Identifikasi penerapan e-commerce meliputi penerapan melalui media World Wide Web (WWW), media Sosial, market-place, dan penggunaan aplikasi-aplikasi mobile baik dari hasil pengembangan sendiri maupun memanfaatkan aplikasi-aplikasi yang sudah ada.

\section{Website atau Content Marketing}

Content marketing adalah strategi pemasaran dimana seorang pelaku bisnis merencanakan, membuat, dan mendistribusikan konten yang mampu menarik audien yang tepat sasaran, kemudian mendorong mereka menjadi customer. Pernyataan pertama untuk mengidentifikasi Content marketing dimulai dengan mengisi alamat Website yang dimiliki oleh usaha mikro dan kecil. Hal ini dikarena pada umumnya strategi pemasaran dengan pendekatan konten sangat efektif jika dilakukan melalui konten yang dimuat melalui website. Hasil identifikasi responden terhadap kemilikan website menunjukkan hanya terdapat 3 responden UMKM yang memiliki alamat website yaitu bit.ly/pipikssnack (https://pipikssnack.business.site/?m=true), https://yellowpages.co.id/bisnis/ika-kimia-sari-cv-epoxy-alteco-puac-pudan mlatiwangi.business.site. Fenomena ini menunjukkan website bukan menjadi pilihan UMKM dalam mengimplementasikan e-commerce bagi bisnisnya. Pernyataan selanjutnya berkaitn dengan pemanfaatan search engine dan ads dalam mengenalkan konten yang dibuat UMKM di berbagai media. Hasil jawaban responden terhadap 3 item penyataan tentang content marketing dapat dilihat dalam gambar berikut: 


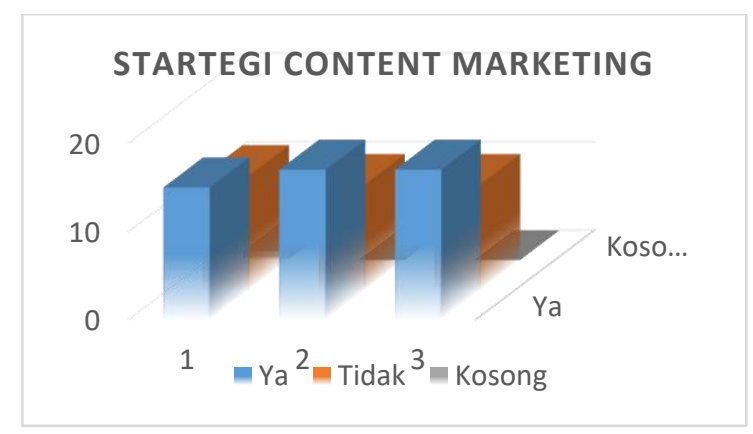

\begin{tabular}{|l|r|r|r|}
\hline Ya & 15 & 17 & 17 \\
\hline Tidak & 13 & 12 & 12 \\
\hline Kosong & 1 & 0 & 0 \\
\hline
\end{tabular}

Sumber: Data Primer diolah 2020

Pernyataan ke-1 yang berkaitan dengan strategi SEO menunjukkan 13 responden atau 52\% menjawab "Ya" dan 11 responden atau 44\% menjawab "Tidak" sedang 1 responden atau 4\% tidak memilih jawaban. Ini mengindikasikan bahwa penggunaan search engine menjadi sarana publikasi bagi konten yang dibuat belum dilakukan secara optimal oleh pelaku UMKM. pernyataan ke-2 dan ke-3 yang berkaitan dengan penggunaan ADS atau iklan-iklan di berbagai media menunjukkan hasil pada kisaran $44 \%$ sampai dengan $56 \%$. Indikasiyang tersirat dalam jawaban responden, pemanfaatan iklan lewat media social lebih dipilih oleh pelaku UMKM dari pada pemanfaatan iklan-iklan baik yang berbayar maupun tidak berbayar.

\section{Media Sosial}

Tidak seperti World Wide Web, media sosial tampaknya lebih popular di kalangan pengusaha mikro kecil dan menengah. Hal ini dibuktikan dengan jawaban atas pernyataan yang berkaitan dengan penggunaan media sosial bagi pelaku UMKM. Ketika responden UMKM diminta untuk memilih media sosial yang digunakan, terdapat 7 media sosial yaitu Facebook, Youtube, Whatsapp, Tweeter, Line, BBM, dan Instagram. Seluruh responden mempunyai media sosial tetapi masing-masing mempunyai jumlah media sosial yang dimilik secara beragam. Whatsapp menjadi aplikasi media sosial dengan pengguna yang tertinggi sebanyak 27 responden atau 93\%. Media sosial terpopuler kedua adalah facebook dengan dipilih oleh 21 responden atau $72 \%$ responden. Kemudian disusul Instagram dengan 17 responden atau 59\% responden. Kemudian Line dengan 8 responden atau 28\% responden. Selebihnya Youtube, Tweeter dan BBM digunakan tidak lebih dari 5 responden atau 
JEMAP: Jurnal Ekonomi, Manajemen, Akuntansi, dan Perpajakan

ISSN: 2622-612X (Media Online) | Vol.4 | No.1 | April 2021

17\% responden. Hasil jawaban responden terhadap 3 item penyataan tentang penggunaan media sosial dapat dilihat dalam gambar berikut:

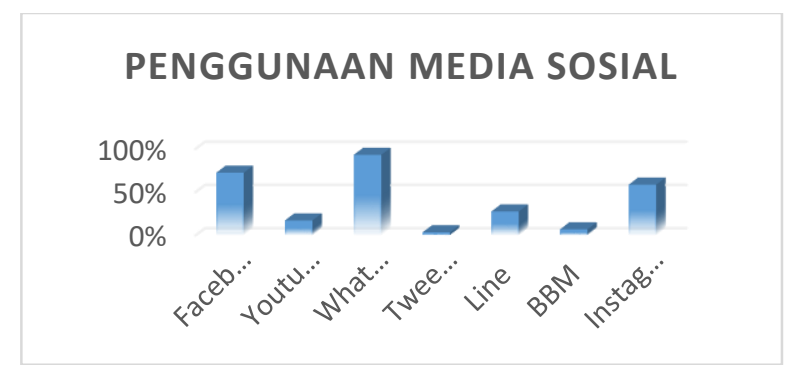

\begin{tabular}{|l|r|}
\hline Facebook & 21 \\
\hline Youtube & 5 \\
\hline Whatsapp & 27 \\
\hline Tweeter & 1 \\
\hline Line & 8 \\
\hline BBM & 2 \\
\hline Instagram & 17 \\
\hline
\end{tabular}

Sumber: Data Primer diolah 2020

\subsubsection{Market Place}

Implementasi e commerce melalui market place cukup direspon baik oleh responden. Hal ini dapat dilihat dari 29 responden yang diminta untuk memilih marketplace yang pernah digunakan terdapat 22 responden atau $76 \%$ yang menggunakan market place untuk menjual produknya. Adapun market place yang digunakan adalah Tokopedia, Bukalapak, Shopee, Facebook marketplace, Gojek, Grab, Instgram dan Maselo. Hasil dari jawaban responden tentang implementasi $e$ commerce dengan menggunakan marketplace dapat dilihat dalam gambar berikut:

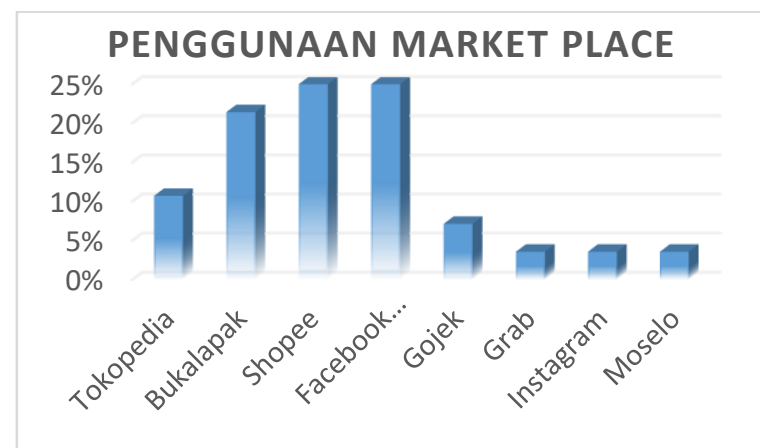

\begin{tabular}{|l|l|}
\hline Tokopedia & 3 \\
\hline Bukalapak & 6 \\
\hline Shopee & 7 \\
\hline Facebook Market Palce & 7 \\
\hline Gojek & 2 \\
\hline Grab & 1 \\
\hline Instagram & 1 \\
\hline Moselo & 1 \\
\hline
\end{tabular}

Sumber: Data Primer diolah 2020

Dari 22 responden atau $76 \%$ responden yang memilih marketplace yang digunakan, Facebook Market Place dan Shopee merupakan marketplace dengan frekuensi tertinggi sebanyak 7 kali atau 25\% dipilih. Sedang Bukalapak menduduki peringkat ke-2 dengan 6 kali dipilih atau 21\%. Tokopedia berada pada strata 
JEMAP: Jurnal Ekonomi, Manajemen, Akuntansi, dan Perpajakan

ISSN: 2622-612X (Media Online) | Vol.4 | No.1 | April 2021

160

berikutnya dengan 3 kali dipilih, Gojek 2 kali dipilih dan Grab, Instagram dan Moselo dipilih sebanyak 1 kali.

\section{Penggunaan Mobile Application}

Tren bisnis online saat ini telah berpindah dari aplikasi desktop ke mobile phone application. Perpindahan tren ini telah dirasakan mulai satu dasawarsa yang lalu dengan ditandai munculnya berbagai marketplace yang mengembangkan aplikasi berbasis android seperti Tokopedia dan Bukalapak. Tidak terkecuali aplikasi gojek dan grab yang dirintis pertama kali dengan memanfaatkan android sebagai basis operating system nya. Gojek dan Grab adalah pelopor utama dari bisnis transportasi yang berkembang kebisnis logistik termasuk layanan go food dan grab food, go shop dan go mart, grab delivery dll. Luasnya layanan ini menarik banyak bisnis termasuk UMKM untuk memanfaatkan layanan yang ditawarkan. Identifikasi terhadap penggunaan mobile application mengacu pada penggunaan kedua aplikasi ini. Hal ini didasarkan pada hasil identifikasi terhadap pemakaian aplikasi gojek dan grab dapat dilihat dalam gambar berikut:

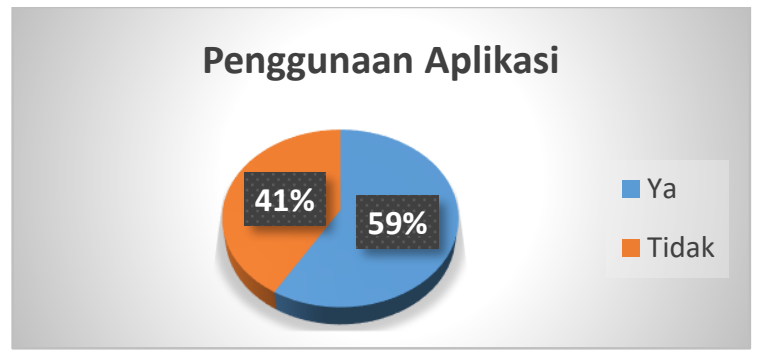

\begin{tabular}{|l|r|}
\hline Ya & 17 \\
\hline Tidak & 12 \\
\hline
\end{tabular}

Sumber: Data Primer diolah 2020

Tabel di atas menunjukkan 17 responden atau 59\% responden menggunakan aplikasi gojek atau grab dalam mengelola bisnisnya.

\section{Dampak Peggunaan E-Commerce}

Identifikasi dampak dari penggunaan e-commerce sebagai media pengembangan bisnis UMKM diukur dengan kontribusi dalam meningkatkan penjualan. Terdapat tiga media yang diukur yaitu dampak World Wide Web, medis sosial dan marketplace. Hasil jawaban responden terhadap dampak penggunaan ecommerce dapat dilihat dalam tabel sebagai berikut: 


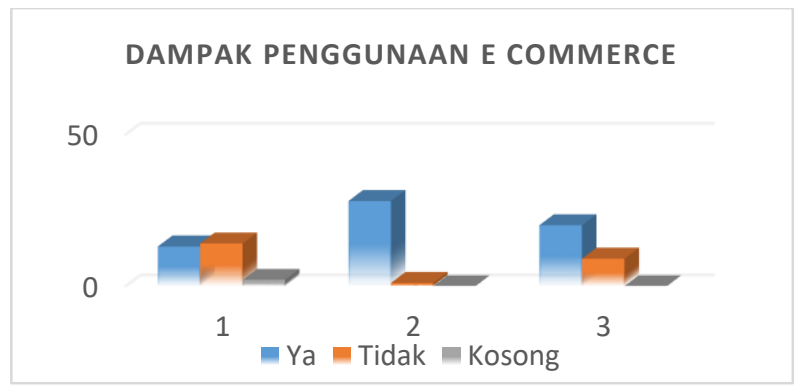

\begin{tabular}{|l|r|r|r|}
\hline & 1 & 2 & \multicolumn{1}{|c|}{3} \\
\hline Ya & $45 \%$ & $97 \%$ & $69 \%$ \\
\hline Tidak & $48 \%$ & $3 \%$ & $31 \%$ \\
\hline Kosong & $7 \%$ & $0 \%$ & $0 \%$ \\
\hline
\end{tabular}

Sumber: Data Primer diolah 2020

Terdapat tiga item pernyataan yang dilontarkan kepada responden dengan jawaban "Ya" atau "Tidak". Pernyataan pertama berkaitan dengan kontribusi penggunaan website bagi penjualan UMKM. pernyataan kedua berkaitan dengan kontribusi penggunaan media sosial bagi penjualan UMKM dan pernyataan ketiga berkaitan dengan kontribusi penggunaan marketplace bagi penjualan UMKM. Hasil rekapitulasi jawaban responden seperti terlihat dalam gambar 4.12. menujukkan social media memberikan dampak tertinggi. Hal ini dapat dilihat dari jawaban responden yang memiih "Ya" sebanyak 28 responden atau sebesar 97\% responden. Sedangkan website dan marketplace dampaknya tidak terlalu signifikan menurut responden, terbukti hanya $45 \%$ responden menjawab "Ya" untuk dampak website dan $69 \%$ responden menjawab "Ya" untuk dampak marketplace bagi penjualan.

\section{PENUTUP}

\section{Kesimpulan}

Hasil rata-rata skor secara agregat, tingkat literasi digital dari pengusaha Mikro dan Kecil (UMK) yang menjadi responden sebesar 79,81\%. Penelitian ini belum bisa memberikan judgement tentang tinggi atau rendahnya score tersebut. Tetapi dilihat dari fenomena tentang pemahaman terhadap teknologi ini, maka rata-rata skor ini telah cukup bagi usaha mikro untuk memulai mengadopsi dan mengadaptasi bisnis secara online.

Kemampuan yang paling menonjol dari responden berkaitan dengan 9 komponen- literasi digital adalah pada pemahaman dan penggunaan media sosial. Hal ini lebih disebabkan oleh kesederhanaan dalam mengoperasikan aplikasi-aplikasi 
JEMAP: Jurnal Ekonomi, Manajemen, Akuntansi, dan Perpajakan

ISSN: 2622-612X (Media Online) | Vol.4 | No.1 | April 2021

media social. Sedangkan yang berkaitan dengan pengembangan konten dan managing digital identity masih relatif kurang. Hal ini dikarenakan pengembangan konten tidak hanya terkait dengan penguasaan opersional teknologi semata tetapi juga daya imaginasi dan kreativitas personalnya menjadi bagian yang sangat penting.

Dari 29 usaha mikro yang terjaring sebagai responden, seluruhnya telah menggunakan media sosial sebagai bagian dari pengelolaan bisnisnya. Sedang pemanfaatan world wide web masih dirasa perlu ditingkatkan. Terbukti hanya 4 dari 29 responden yang telah memiliki world wide web (website).

\section{DAFTAR PUSTAKA}

Bawden, D. 2001. "Information and Digital Literacies: A Review of Concepts " in Journal of Documentation, 57(2), 218-259.

Gerakan Literasi Nasional, Kementerian Pendidikan Jakarta 2017

https://jateng.tribunnews.com/2019/08/29/pemkot-semarang-siap-fasilitasi-umkmmenembus-pasar-asean

https://katadata.co.id/berita/2019/02/12/kontribusi-e-commerce-ke-pdb-diproyeksirp-2305-triliun-pada-2030

Lubis, T. Aurora dan Junaidi, 2016. "Pemanfaatan Teknologi Informasi pada Usaha Mikro Kecil dan Menengah di Kota Jambi”, Jurnal Perspektif Pembiayaan dan Pembangunan Daerah Vol. 3 No. 3, Januari-Maret 2016

Miles, B. Mathew dan Michael Huberman. 1992. Analisis Data Kualitatif Buku Sumber Tentang Metode-metode Baru. Jakarta: UIP.

Wheeler, Steve. 2012. Digital literacies for engagement inemerging online cultures. eLC Research Paper Series, 5, 14-25 